\title{
Identification of promising wheat genotypes for crossing
}

\author{
Luciana Costa ${ }^{1}{ }^{*}$, Carlos Roberto Riede $^{2}$, Claudemir Zucareli $^{1}$, Valéria Carpentieri Pípolo ${ }^{1}$ and Deoclécio Domingos Garbuglio ${ }^{2}$
}

Received 8 February 2010

Accepted 20 May 2010

\begin{abstract}
The objective of this study was to identify promising wheat genotypes from the IAPAR breeding program for crosses by multivariate techniques. Measures of dissimilarity between genotypes were obtained from multicategoric variables. To identify clusters, Tocher optimization and UPGMA were used. The genotypes were divided into five diverging groups, indicating a wide genetic base of the wheat breeding program of the Agricultural Research Institute of Parana (IAPAR). As indicated by the genetic distance, crosses involving the cultivars IPR 85 and IPR 118 seem to be the most promising to increase genetic gains in both grain and flour quality as well as for agronomic parameters.
\end{abstract}

Key words: Triticum aestivum L., genetic improvement, multivariate analysis.

\section{INTRODUCTION}

In recent years, the development of more productive wheat varieties with higher industrial quality has significantly increased. Due to selection by farmers and more recently with scientific research work, both wheat area and yield have increased in Brazil (Bacaltchuck and Silva 2001).

Since wheat production in Brazil was 5.02 million tons in 2009 (Conab 2010), covering only part of the national demand, efforts should be made to develop new cultivars to supply the domestic market in coming years.

In breeding programs using hybridization, as in the case of wheat, the parental selection is the first stage of a breeding program. According to Harlan (1992), the variability within and between species is closely related to their evolution.
In the Wheat Breeding Program of the Agricultural Research Institute of Paraná (IAPAR) hundreds of crosses are performed each year between adapted varieties and sources of characteristics required for cultivation and industrialization of new cultivars for high yield potential, resistance to biotic and abiotic stresses and technological quality (Riede 2001).

Since the beginning of the domestication process, wheat was subjected to intensive human manipulation, altering the genetic basis (Bered et al. 2000). Wheat is a young species, derived from few plants, limiting the genetic diversity. To overcome a series of biotic and abiotic barriers, an expansion of the genetic diversity in wheat has become imperative (Cunha et al. 2008).

Knowledge on the differences in genetic constitutions within or between groups of genotypes is highly important for any breeding program. The importance is given by the

\footnotetext{
${ }^{1}$ Universidade Estadual de Londrina (UEL), Departamento de Agronomia, C.P. 6001, 86.051-970, Londrina, PR, Brazil. *E-mail: luciana.agrouel@yahoo.com.br ${ }^{2}$ Instituto Agronômico do Paraná (IAPAR), C.P. 481, 86.001-970, Londrina, PR, Brazil
} 
need to identify parents with genetic differences that produce progenies with higher heterosis, thus increasing the probability of obtaining improved plants (Cruz and Regazzi 1997).

For the success of a breeding program it is necessary to compile as much relevant information as possible on the germplasm to be used (Souza et al. 2005). For Moura et al. (1999), the determination of genetic dissimilarity, by the evaluation of multiple traits, can be an efficient tool to identify superior genotypes. Based on genetic distance estimates, it is possible to select parents for the formation of breeding populations.

Morphological traits have been widely used in combination with multivariate techniques to quantify the genetic distance in annual crops such as wheat (Reis et al. 1999, Cruz et al. 2004, Bertan et al. 2006).

Genetic diversity can be quantified by multivariate procedures, which are usually complemented by agglomerative and hierarchical clustering methods, e.g., the Tocher method (Rao 1952) and the unweighted pairgroup method using arithmetic averages (UPGMA) (Ivoglo et al. 2008).

The objective of this study was to identify promising wheat genotypes of the IAPAR breeding program to be used in crosses based on the genetic divergence estimated by multivariate techniques.

\section{MATERIALAND METHODS}

Fourteen wheat genotypes of the IAPAR Program for Genetic Wheat Improvement were evaluated, of which nine cultivars (IPR 85, IPR 87, IPR 110, IPR 118, IPR 128, IPR 129, IPR 130, IPR 136, and IPR 144) and five advanced lines (LD 052114, LD 072212, LD 081207, LD 072210, and LD 081105).

The data of morphological and agronomic genotypes were obtained in DUS tests (Distinctness, Uniformity and Stability), according to criteria established by the Ministry of Agriculture, Animal Husbandry and Supply (1998). The experiments were conducted in two growing seasons in 2007 and 2008 at the Experimental Station IAPAR in Londrina (lat $23^{\circ} 23^{\prime} \mathrm{S}$, long $50^{\circ} 11^{\prime} \mathrm{W}$, alt $610 \mathrm{~m}$ asl) (Caviglione et al. 2000).

A total of 30 phenotypic traits were evaluated as proposed by Scheeren (1984): days from emergence to flowering, days from emergence to maturity, tolerance to pre-harvest sprouting, plant height in $\mathrm{cm}$; reaction to lodging; growth habit; tolerance to aluminum toxicity; bioclimatic group, ear length in $\mathrm{mm}$, presence of awns; ear density in $\mathrm{mm}$; ear coloration; ear position; ear shape; auricle color; leaf blade position; sheath waxiness; shape of the upper node; stem diameter in $\mathrm{cm}$; stem wall thickness; stem waxiness; length of the glume tooth in $\mathrm{mm}$; glume length in $\mathrm{mm}$; glume width in $\mathrm{mm}$; glume pubescence; glume shoulder; grain color; grain length in $\mathrm{mm}$; grain shape; and grain texture.

For the dissimilarity analysis, quantitative were converted to multicategoric variables, based on the frequency distribution. For each class a value was assigned, and the data of each accession were rescored based on this scale. For the other variables, the classes proposed in Minimum Wheat Descriptors (BRAZIL 1998) were used. The equation of Cruz (2001) was used to calculate the genetic dissimilarity based on the converted multicategoric variables, where: Diss $=1-\{C /(C+D)\}$, where $\mathrm{C}$ represents the number of matching values between two accessions and $\mathrm{D}$ represents the number of discrepant values between two accessions, both for a particular set of variables on a muticategoric scale.

Based on the genetic distance matrix, a dendrogram was constructed using the Unweighted Pair Group Method (UPGMA). The groups were determined by the Tocher optimization method.

Genetic-statistical analyses were performed using Statistica 6.0 (Hill and Lewicki 2005) software.

\section{RESULTS AND DISCUSSION}

A representative dendrogram was constructed based on the UPGMA clustering method (Figure 1) and the genotypes were grouped by Tocher into five distinct groups of genetic similarity (Table 1).

The first group consisted of genotype IPR 85, group II contained IPR 87, group III IPR 128, IPR 130, IPR 136, LD 052114, LD 072212, LD 081207, LD 072210, and LD 081105,

Table 1. Clustering of 14 wheat genotypes by the Tocher clustering method

\begin{tabular}{cl}
\hline Cluster & \multicolumn{1}{c}{ Genotypes } \\
\hline I & IPR 85 \\
II & IPR 87 \\
III & IPR 128, IPR 130, IPR 136, LD 052114 \\
& LD 072212, LD 081207, LD 072210, and LD 081105 \\
IV & IPR 129 and IPR 144 \\
V & IPR 110 and IPR 118 \\
\hline
\end{tabular}


group IV contained IPR 129 and IPR 144 and group V the cultivars IPR 110 and IPR 118.

The dendrogram showed that the most distant genotype from the others was cultivar IPR 85 (group I) resulting from a cross involving Brazilian and Mexican germplasm. Group II contained IPR 87, derived from a cross between Coodetec and IAPAR germplasm.

The more complex group III can be subdivided in three subgroups and explained as follows:

The cultivars IPR 128, IPR 130 and LD 052114 were derived from Mexican germplasm, introduced or crossed among each other. LD 072210 and LD 072212 are sister lines and both progenies of LD 8710 which is derived from an $\mathrm{F}_{2}$ population introduced from the International Maize and Wheat Improvement Center (CIMMYT) and selected for uniformity of the main traits in Londrina, and crossed with PF 950156, a line of Embrapa Trigo. Cultivar IPR 136 is derived from a cross between American and Mexican germplasm, with medium maturation cycle.

The genotypes LD 081207 and LD 081105 have the parent IPR 84 (Table 2) in common, besides Mexican germplasm used as parents in the other lines.

Table 2. Crosses originating the study genotypes

\begin{tabular}{cl}
\hline Genotypes & \multicolumn{1}{c}{ Crosses $^{1}$} \\
\hline IPR 85 & IAPAR 30/BR 18 \\
IPR 87 & IOC878/IAPAR 29 \\
IPR 110 & PF 85202/OC852 \\
IPR 118 & OC852/PG8852 \\
IPR 128 & VEE/LIRA//BOW/3/BCN/4/KAUZ \\
IPR 129 & IA 976/LD 972 \\
IPR 130 & RAYON//VEE\#6/TRAP\#1 \\
IPR 136 & TAW/SARA//BAU/3/ND674*2/IAPAR 29 \\
IPR 144 & SERI*3/BUC/5/BOW/3/CAR 853/COC//VEE/4/OC 22 \\
LD 052114 & BR 18/IA 8719//CMH 83.2517 \\
LD 072212 & LD 8710/PF 950156 \\
LD 081207 & NANGING 8343/KAUZ//IPR 84 \\
LD 072210 & LD 8710/PF 950156 \\
LD 081105 & LD 975//IPR 84/IPR 85 \\
\hline
\end{tabular}

Group IV contained the cultivars IPR 129 and IPR 144, both early-maturing and derived from crosses between Brazilian and Mexican germplasm. It can be verified that the Tocher analysis group V united the genotypes IPR 110 and IPR 118 originated from Brazilian germplasm with the common parent line OC 852.

In a similar study, Reis et al. (1999) used multivariate techniques as divergence measures of 15 wheat cultivars recommended in the Central Region of the country and five cultivars with significant participation in the Brazilian germplasm. The evaluated genotypes were highly divergent, as also observed in this study.

Cruz et al. (2004) estimated the genetic dissimilarity of 14 wheat genotypes based on lodging-related traits and found great variability among the genotypes for this trait.

In another study on the genetic similarity of 50 wheat cultivars detected by RAPD markers, Bered et al. (2000) noted that the genetic base of wheat available for breeding in Brazil is very narrow. These discrepant results from other studies in the area can be explained by the study methodology (RAPD). RAPD has not proven effective for detecting variability in wheat due to the complex genome (allohexaploid) of this cereal, according to results of Devos and Gale (1992) in England and He et al. (1992) and Riede et al. (1994) in the United States. Besides, the genotypes studies were mostly specifically adapted to environments of cold and rainy climate and acidic soils.

Bertan et al. (2006) evaluated the genetic similarity among wheat cultivars for blight-related traits and found variability for aluminum tolerance among the genotypes.

In breeding programs, the parents must have great genetic divergence and high means of performance for the target traits of breeding (Benin et al. 2003). In this sense, the following crosses can be expected to be promising: IPR 110 with IPR 129, IPR 136, and IPR 130; IPR 118 with LD 081207, IPR 136, IPR 144, IPR 130, IPR 85, and LD 081105; IPR 85 with IPR 144, IR 110, IPR 129, IPR 130, 136, LD 081207, and LD 081105, since the genotypes were dissimilar (Figure 1) and the agronomic and/or quality parameters were appropriate. This information for the lines was obtained from internal data of the IAPAR Breeding Program and from Bassoi et al. (2008) and Bassoi et al. (2009) for the cultivars. These crosses could increase the number of desired recombinant lines that could be used as sources of superior genotypes.

Among the most targeted traits in wheat breeding programs are those related to industrial quality, eg., grain and flour quality. For these, the indication of crosses should include dissimilar genetic constitutions and superior quality parameters. From this point of view, crosses between IPR 85 x LD 081207, IPR 85 x IPR 136, IPR 85 x IPR 130 and IPR 85 x IPR 144 (Figure 1, Table 1) are recommended. The use of these parents in crossing blocks allows breeders to focus on segregation related to other agronomic parameters, since the indicated crosses should provide segregating populations of high industrial quality. 


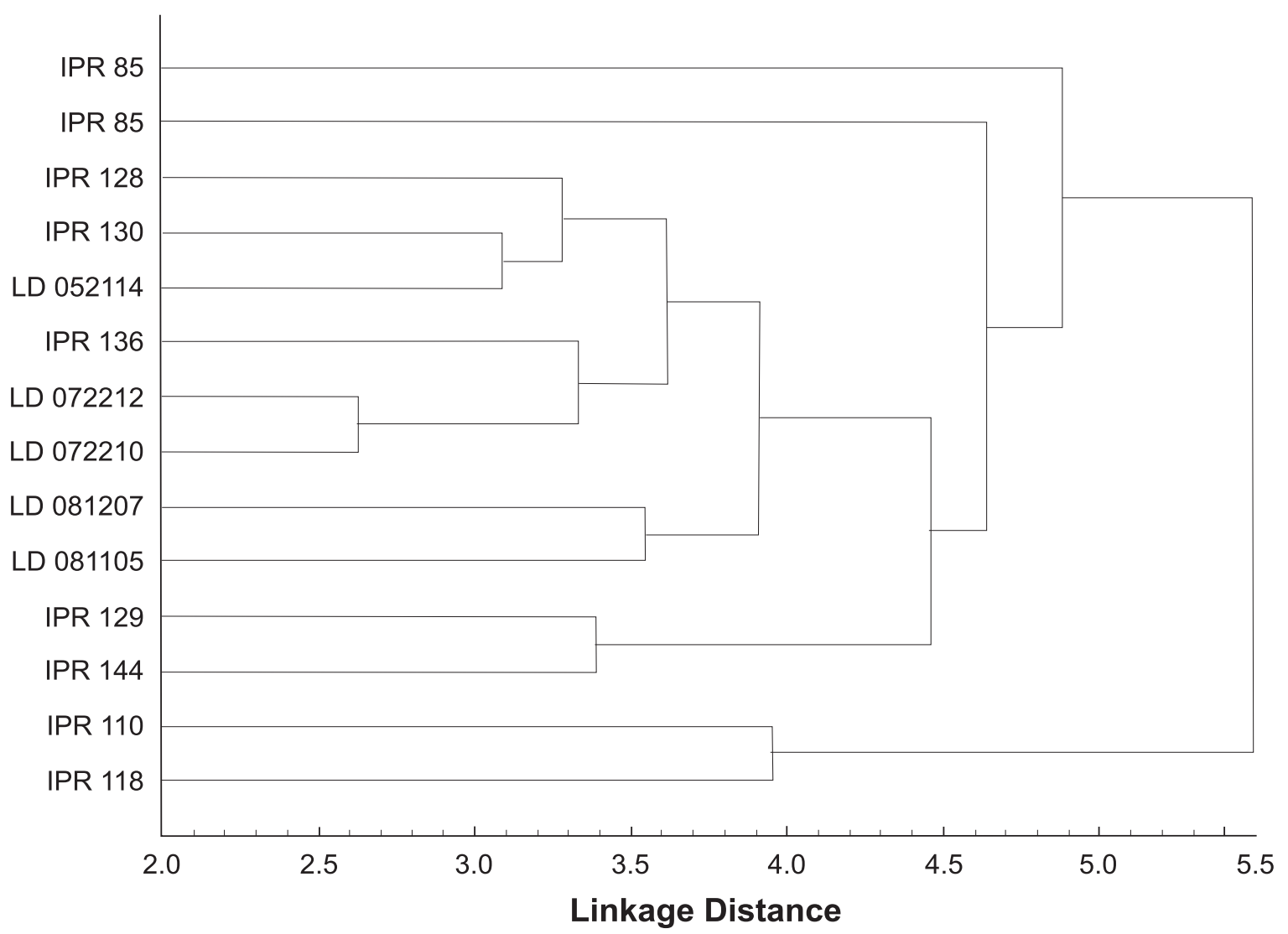

Figure 1. Dendrogram resulting from the analysis of 14 wheat genotypes (based on 30 morphological traits), obtained by the UPGMA clustering method.

Based on UPGMA and Tocher clustering (Table 1, Figure 1), crosses involving the cultivars IPR 85 and IPR 118 (genotypes of good grain and flour quality, with high agronomic potential), allocated in different groups, may be the most promising to increase genetic gain for both grain and flour quality as well as for agronomic parameters. The industrial quality of cultivar IPR 85 is excellent and it has early maturity, pendant ears and hard grains. The flour quality depends primarily on two interrelated grain traits: protein content and hardness. Hardness is a parameter that affects the time of grain conditioning or storage before milling and influences the pattern of endosperm breakage, ease of separating endosperm from bran, flour particle size, release of break flour and energy consumption during milling (El Dash and Camargo 1982). The water absorption of hard kernel flour is high (desirable in bread) and protein contents higher than of soft wheat (Guarienti 1996). Cultivar IPR 118 has semi-hard grain texture and has similar traits of ear position and early maturity as IPR 85 , which according to Felicio et al. (1983), has the shortest period of crop land cover, allowing the cultivation of other crops soon after wheat harvest, with time enough for soil preparation. Genotype IPR 118 is also highly tolerant to aluminum soil toxicity. Considering the importance of this trait for genetic wheat improvement due to root growth restrictions and interference with nutrient uptake (Silva et al. 1984), the need to develop superior genotypes for this character becomes evident (Bertan et al. 2006). The divergence analysis of the involved genotypes, allocated them into five different groups, and showed that the genetic base of the wheat breeding program of IAPAR is wide. These results may help researchers in the choice of parents.

\section{ACKNOWLEDGEMENTS}

The authors thank the Fundação Araucária for financing this research. 


\title{
Identificação de genótipos de trigo promissores para cruzamentos
}

\begin{abstract}
RESUMO - O objetivo do trabalho foi identificar genótipos de trigo, provenientes do Programa de Melhoramento Genético do IAPAR, promissores para cruzamentos, por meio de técnicas multivariadas. As medidas de dissimilaridade entre os genótipos foram obtidas a partir de variáveis multicategóricas. Para identificação dos agrupamentos foi utilizado o método de otimização de Tocher e o hierárquico UPGMA. Os genótipos avaliados foram alocados em cinco grupos divergentes, indicando que a base genética do programa de melhoramento de trigo do IAPAR é ampla. Com base na distância genética, cruzamentos artificiais envolvendo as cultivares IPR 85 e IPR 118 podem ser os mais promissores no intuito de incrementar o ganho genético, tanto para a qualidade de grãos e de farinha quanto para parâmetros agronômicos.
\end{abstract}

Palavras-chave: Triticum aestivum L., melhoramento genético, análise multivariada.

\section{REFERENCES}

Bacaltchuk B and Silva HRC (2001) Nasce uma nova era: o trigo recupera sua nobreza. Embrapa Trigo, Passo Fundo, 172p.

Bassoi MC, Riede CR, Fronza V, Campos LAC, Tavares LCV, Shioga PS, Miranda LC, Scholz MBS, Beckert OP, Okuyama LA, Scheeren PL, Pola JN, Mirnada MZ and Azambuja JFS (2008) Cultivares de trigo Embrapa e Iapar. Embrapa Soja, Londrina, 64p. (Documento, 303)

Bassoi MC, Riede CR, Campos LAC, Fronza V, Tavares LCV, Shioga PS, Miranda LC, Scholz MBS, Beckert OP, Okuyama LA, Machado JC, Scheeren PL, Pola JN, Sera GH, Mirnada MZ, Azambuja JFS and Dengler RU (2009) Cultivares de trigo Embrapa e Iapar. Embrapa Soja, Londrina, 56p. (Documento, 311)

BRASIL (1998) Secretaria de Desenvolvimento Rural. Serviço Nacional de Proteção de Cultivares. Portaria, n.215, de 14 de julho de 1998. Diário Oficial da República Federativa do Brasil, Brasília, n.134, p.38-41, 16 julho 2000, Seção 1.

Benin G, Carvalho FIF, Oliveira AC, Marchioro VS, Lorencetti C, Kurek A, Silva JAG, Cruz PJ, Hartwig I and Schmidt DAM (2003) Comparação entre medidas de dissimilaridade e estatística multivariadas como critérios no direcionamento de hibridação de aveia. Ciência Rural 33: 657-662.

Bered F, Carvalho FIF and Barbosa Neto JF (2000) Variabilidade genética em trigo. Biotecnologia, Ciência e Desenvolvimento 14: $22-25$.

Bertan I, Carvalho FI, Oliveira AC, Silva JAG, Benin G, Vieira EA, Silva GO, Hartwig I, Valério IP and Finatto T (2006) Dissimilaridade genética entre genótipos de trigo avaliados em cultivo hidropônico sob estresse por alumínio. Bragantia 65: $55-63$.

Caviglione JH, Caramori PH, Kiihl, LRB and Oliveira D (2000) Cartas climáticas do Paraná. IAPAR, Londrina. (CD-ROM).
CONAB - Companhia Nacional de Abastecimento (2010) Acompanhamento de safra brasileira: grãos, quarto levantamento. Available at http://www.conab.gov.br. Asseessed on Feb 2, 2010.

Cruz CD (2001) Programa GENES-versão Windows: aplicativo computacional em genética e estatística. Editora UFV, Viçosa, $648 \mathrm{p}$.

Cruz CD and Regazzi AJ (1997) Modelos biométricos aplicados ao melhoramento genético. Editora UFV, Viçosa, 390p.

Cruz PJ, Carvalho FIF, Oliveira AC, Benin G, Vieira EA, Silva JAG, Valério IP, Hartwig I and Busato CC (2004) Genetic dissimilarity among wheat genotypes for lodging associated traits. Crop Breeding and Applied Biotechnology 4: 427-433.

Cunha GR, Pires JLF and Dalmago GA (2008) Em busca da melhoria da eficiência no uso de recursos do ambiente. Revista Plantio Direto 105: 16-20.

Devos KM and Gale MD (1992) The use of random amplified polymorphic DNA markers in wheat. Theoretical and Applied Genetics 84: 567-572.

El Dash AA and Camargo CRO (1982) Fundamentos da tecnologia de panificação. Secretaria da Indústria, Comércio e Tecnologia, São Paulo, 400p.

Felício JC, Barros BC, Camargo CEO and Bar WR (1983) Maracaí (IAC 17) e Xavantes (IAC 18): cultivares de trigo para o Estado de São Paulo. Bragantia 42: 15-25.

Guarienti EM (1996) Qualidade industrial de trigo. Embrapa, Passo Fundo, 36p. (Documento, 27)

Ivoglo MG, Fazuoli FC, Oliveira ACB, Gallo PB, Mistro JC, Silvarolla MB and Toma-Braghini M (2008) Divergência genética entre progênies de café robusta. Bragantia 67: 823-831.

Harlan JR (1992) Crops and man. American Society of Agronomy and Crop Science, Madison, 284p. 
He S, Ohm H and Mackenzie S (1992) Detection of DNA sequence polymorphisms among wheat varieties. Theoretical and Applied Genetics 84: 573-578.

Hill T and Lewicki P (2005) STATISTICS methods and applications. StatSoft, Tulsa, 800p.

Ivoglo MG, Fazuoli FC, Oliveira ACB, Gallo PB, Mistro JC, Silvarolla MB and Toma-Braghini M (2008) Divergência genética entre progênies de café robusta. Bragantia 67: 823-831.

Harlan JR (1992) Crops and man. American Society of Agronomy and Crop Science, Madison, 284p.

MAPA - Ministério da Agricultura e Abastecimento (1998) Legislação brasileira sobre proteção de cultivares. MA/ SDR/SNPC, Brasília, 73p.

Moura WM, Casali VWD, Cruz CD and Lima PC (1999) Divergência genética em linhagens de pimentão em relação a eficiência nutricional de fósforo. Pesquisa Agropecuária Brasileira 34: 217-224.

Rao RC (1952) Advanced statistical methods in biometric research. John Wiley, New York, 390p.
Reis WP, Vello NA, Ferreira DF and Ramalho MAP (1999) Associação entre coeficiente de parentesco e técnicas multivariadas como medidas de dissimilaridade genética de cultivares de trigo. Ciência e Agrotecnologia 23: 258-269.

Riede CR, Fairbanks DJ, Andersen WR, Kehrer RL and Robison LR (1994) Enhancement of RAPD analysis by restrictionendonuclease digestion of template DNA in wheat. Plant Breeding 113: 254-257.

Riede CR (2001) IAPAR - Pesquisando trigo para o Paraná. In Cunha G (ed.) Trigo no Brasil: história e tecnologia de produção. Embrapa Trigo, Passo Fundo, p. 81-86.

Sheeren PL (1984) Instruções para utilização de descritores de trigo (Triticum spp.) e triticale (Triticosecale sp.). Embrapa-CNPt, Passo Fundo, 32p. (Documento, 9)

Silva JBC, Novais RF and Sediyama CS (1984) Comportamento de genótipos de soja em solo com alta saturação de alumínio. Pesquisa Agropecuária Brasileira 19: 287-298.

Souza FF, Queiroz MA and Dias RCS (2005) Divergência genética em linhagens de melancia. Horticultura Brasileira 23: 179183. 